DOI: http://dx.doi.org/10.12775/szhf.2014.017

\author{
KAZIMIERZ BRODZIŃSKI
}

\title{
Sztuki piękne*
}

Gdyśmy już poznali co jest wzniosłość i piękność, jak te dwa żywoty sztuk pięknych łączą się z sobą, przystąpmy już do samych sztuk pięknych.

Nadmieniłem już w pierwszej lekcji o zmysłach szlachetniejszych, to jest oka i słuchu ${ }^{1}$, przez które człowiek jedynie wyobrażeń nabiera i przez które

* Kazimierz Brodziński (1791-1835) - polski poeta, teoretyk sztuki, krytyk literacki, pierwszy tłumacz wczesnej myśli estetycznej Immanuela Kanta zawartej w Rozważaniach o uczuciu piękna i wzniosłości. Rozmyślania, jakie zrodziły się w czasie tłumaczenia, pozwoliły napisać Brodzińskiemu obszerny artykuł zatytułowany Piękno i wzniosłość, który ukazał się drukiem w 1834 roku w „Jutrzence Warszawskiej”.

Fragment zatytułowany Sztuki piękne stanowi drugą część kursu estetyki, który Brodziński wygłaszał na Uniwersytecie Warszawskim w latach 1825-1827. Kurs estetyki wydany został drukiem w 1873 roku w V tomie Pism Kazimierza Brodzińskiego przez J. Kraszewskiego w Poznaniu. Ponieważ pierwszą część wykładów stanowi fragment bardziej znanego i kilkakrotnie drukowanego artykułu Piękno i wzniosłość, została ona przeze mnie celowo pominięta. W następnych numerach „Studiów z Historii Filozofii” ukażą się dwa kolejne fragmenty Kursu estetyki. Ostatnia część przedrukowywanych urywków zostanie poprzedzona teoretycznym artykułem ukazującym estetykę Brodzińskiego na tle XVIII-wiecznej myśli o sztuce.

${ }^{1}$ Trudno dzisiaj stwierdzić, skąd pierwotnie pochodził podział na zmysły niższego rzędu (smak, dotyk i węch), które nie dostarczają przeżycia piękna, a zmysły wzroku i słuchu jako bardziej szlachetne, których przyjemności nie są samym doznaniem, ale zdolnością rozkoszowania się harmonią i ładem pomiędzy poszczególnymi bodźcami. Na pewno taki podział istniał już u Arystotelesa w Etyce Eudemejskiej (1230 b31). Pogląd ten był rozpowszechniony zwłaszcza w XVIII wieku. Znajdziemy go w estetyce Addisona, Du Bos i mniej bezpośrednio w koncepcji Shaftesburego. 
zebrał zapasy swojej imaginacji². Stąd i piękne sztuki na dwa główne działy rozłożyć się dają, to jest te, które należą do zamysłu widzenia i do zmysłu słyszenia. Do tych dołącza się trzecia, która nie do zmysłów, ale za pomocą tych dwóch zmysłów wprost do duszy przemawia, to jest poezja.

Słuch jest pierwszym zmysłem, który uczucia, jakich przyczynę i początek pojąć możemy, duszy naszej przesyła. W dźwięku może się zawierać czułość, wesołość, smutek, rozpacz i inne namiętne wyrażenia wzruszonej duszy. I stąd przez dźwięk może się dać uczuć innej duszy. Najpierwsza i najsilniejsza ze wszystkich, która do duszy drogę przez ucho obiera, jest muzyka. Prawda, że i mowa działa na ucho, ale dźwięk nie jest głównym jej celem. Tu dźwięk jest tylko środnik pomocniczym, który nadaje wyobrażeniom więcej mocy i ułudzenia. Główny cel poezji i wymowy nie zawisł na dźwięku, ale na znaczeniu słów.

Wrażenia, które pojmujemy przez oko, nie są tak mocne, jak te, które działają na ucho, ale przechodzą je za to w objętości i rozmaitości. Oko nieukończenie dalej sięga niżeli ucho. Tamte wyrażają ciąg rozmaitych uczuć bez wyrażenia rzeczy zewnętrznych, te dają nam poznać przedmioty w postaciach, to jest zewnętrznych nas. Tamtych rzeczą jest czas, tych przestrzeń ${ }^{3}$. Do tych więc należy głównie malarstwo. Obydwie te główne sztuki działają na zmysły i wewnętrzne uczucie. Ale jest sztuka, która działa bezpośrednio na wewnętrzne uczucie. Tą sztuką jest poezja sama przez się. Ludzki geniusz nadał myślom i wyobrażeniom, które nic zmysłowego nie mają, pewne formy, przez które z duszy do duszy przechodzą. Takie formy obejmuje mowa. Mowa może za pomocą słuchu i oka każde wyobrażenie przenieść do duszy. Moc jego znaczenia nie polega ani na brzmieniu, ani na postaci, jaką ma w piśmie. Jest to więc coś zupełnie umysłowego w przypadkowej zmysłowej postaci, aby przez zmysły do duszy wcisnąć się mogło. Użyjcie tej sztuki, daleko jest obszerniejsze niż innych. Jakiekolwiek wyobrażenie albo uczucie chcemy duszy przedstawić, do tego mowa najskorsze podaje środki. Za pomocą cudownych jej znaków, każde wyobrażenie najłatwiej i najpewniej sobie przypomnimy.

\footnotetext{
${ }^{2}$ Warto porównać zbliżone obserwacje w estetyce Josepha Addison'a i Jeana-Baptista Du Bos. Por. J. Addison, O przyjemnościach wyobraźni, tłum. P. Parszutowicz, „Terminus”, 1/2004 oraz J.-B. Du Bos, Refleksje krytyczne o poezji i malarstwie, tłum. Agnieszka Morawińska, [w:] Europejskie źródła myśli estetyczno-literackiej polskiego oświecenia. Antologia wypowiedzi pisarzy francuskich, niemieckojęzycznych $i$ angielskich 1674-1810, s. 122-153.

${ }^{3}$ Por. J.-B. Du Bos, Refleksje krytyczne oraz G. E. Lessing, Laokoon czyli O granicach malarstwa i poezji, tłum. J. M. Białostocka, Wrocław 1962.
} 
Przeto jest ona co do żywości wyobrażeń najsłabszą, ale najmocniejszą przez to, że jest zdolną obudzić wszelkie tychże wyobrażeń rodzaje $e^{4}$.

Te są trzy główne sztuk gatunki. Ale lubo każda ma swój oddzielny przymiot, przecież najściślej połączone są z sobą. Prawa jednej są po większej części prawami dla drugiej. Wymyślono dzieła sztuki, gdzie dwie lub trzy razem się łączą. W tańcu np. łączą się sztuki, które razem są rozkoszą dla ucha i oka. W pieśniach łączy się mowa z muzyką, a w sztuce dramatycznej mogą wszystkie skutecznie się wspierać. Dlatego to działa teatralne są najpóźniejszym i najwyższym wynalazkiem sztuki. Każda sztuka ma znowu swoje gałęzie, jest w każdej sztuce rodzaj, który samo tylko podobanie się ma na celu. Do tego należą w poezji ulotne twory i dowcipne: w malarstwie kwiaty, krajobrazy, które tylko są piękne bez wyrażania pewnej namiętności lub charakteru $^{5}$; w muzyce sztuki, w których prócz harmonii i rytmu, mało co jest do uważania. Inne gałęzie dążą wyłącznie do doskonałości i prawdy, jak np. wyższe rodzaje poezji, historyczne obrazy, muzyczne oratoria itp.

W ogólności, według tych trzech głównych podziałów sztuk, rozłożyć je można jak następuje:

1. Poezja w całej obszerności wyrazu.

2. Muzyka, równie w całej obszerności.

3. Malarstwo.

4. Rzeźbiarstwo.

5. Architektura, do której można policzyć wyższe ogrodnictwo.

6. Taniec.

7. Sztuka teatralna.

Każda $\mathrm{z}$ tych siedmiu sztuk należy do jednego $\mathrm{z}$ trzech głównych oddziałów, różnią się tylko przez połączenie mniej lub więcej ścisłe [ściśle] z innymi.

Estetyka nie trudni się wcale ścisłym wykładem każdej szczególnej sztuki. Jej rzeczą jest tylko doskonały smak, który wszystkim towarzyszyć powinien. Kto pod względem estetycznym jedną tylko z tych sztuk doskonale rozpozna, już tem samym pojmie własności innych, i dla tego piękne sztuki są jak muzy wiecznie zgodnymi siostrami.

Uprzedzam, że nie myślę nawet pod samym estetycznym względem, mówić o każdej z tych sztuk w szczególności. Główną rzeczą moją będzie poezja,

\footnotetext{
${ }^{4}$ Podobne rozważania znajdziemy także w estetyce Addisona. Por. J. Addison, O przyjemnościach wyobraźni, s. 198 i nn.

${ }^{5} \mathrm{~W}$ estetyce XVII i XVIII wieku istniało przekonanie o tym, że tylko wielkie, umoralniające tematy są w stanie przyciągnąć uwagę widza na dłużej i stają się przez to bardziej interesujące. Por. J.-B. Du Bos, Refleksje krytyczne o poezji i malarstwie, rozdz. X, s. 128-129.
} 
jako źródło najbogatsze i najpowszechniejsze, z którego inne sztuki wypływają, i której ogólne prawidła mogą służyć dla wszystkich w szczególności.

Ile mi okoliczność pozwoli, nadmienię o innych pięknych sztukach to, w czym z poezją najbliższy mają związek, co posłuży więcej do zamiłowania i znania sztuk pięknych, niżeli do ich wykonywania.

Niemcy, którzy wszystkie nauki uogólniać lubią, zawikłali się w zbyt trudne teorie, jakich wymaga podciągnięcie wszystkich sztuk pięknych pod ogólne prawidła. To przechodzi siły piszącego i pojęcie czytelnika. Metafizycy chcieli je pociągnąć do jednej ogólnej zasady, ale tę tak wznieśli wysoko, że jej pojęcia jasno widzieć i rozpoznać nie można. Inni chcieli przez mnóstwo podziałów rozebrać na części ogólną naukę, mogącą się zastosować do każdej sztuki, ale dążąc do ogólności, stracili z oka jedność. Istotnie każda sztuka okazuje się w swojej sferze szczególnej, tak właśnie jak części kraju, które z innymi jedno państwo składają, ale które mają osobne swoje zwyczaje, przywileje, wyłączenia i oddzielny charakter przez naturę wskazany. Można sobie wyobrazić, jakich by potrzeba wiadomości i sposobu wykładu, ażeby zgłębić teorię wszystkich szczególnych sztuk, gdy to zaledwie z jedną w zupełności uczynić można. Wszyscy, którzy się o to kusili, stali się albo ciemnymi, lub musieli teorię swą powikłać, podzielić na niezliczone części, a przy każdej ogólnej zasadzie oglądać się na mnóstwo różnic i wyjątków.

Oto jeszcze, przez to teoretyczna filozofia Niemców uczyniła z estetyki oddział najwięcej zawikłany, podzielony, a najmniej zupełny. Jest to część filozofii najpóźniejszej, ale myślę, że bardzo daleko jest od zupełnego wykończenia. Mojem zdaniem tajemnicy piękności tak jak wiele przedmiotów badań naszych, nie chciała nam natura odsłonić, dozwoliła nam tylko częściowo uchylić zasłonę; może w tym miała także swój widok, albo lubych omamień przez rzeczywistość nie zburzyć. Dlatego to i w naszych tworach najwyższą tajemnicą sztuki jest ukrywać sztukę.

Dalecy więc od tego sposobu, z którego wiele pracy, a mało korzyści, trzymajmy się prostoty, i ograniczmy się do tego, co jasno objąć się daje.

In teresowność - zajęcie. Cechą doskonałości i głównym celem każdego pisma jest, aby było interesowne. $Z$ tych względów obowiązanym jestem obstawać równie za prawami rozumu jak czucia, z kolei włożę naprzód jak i przez co dzieło może nasz rozum zajmować. Do wyrażenia interesowności nie znajduję słowa w polskim języku, nie mają go też i inne żyjące języ- 
ki. - Interesownym nazywamy to, co całą naszą uwagę pociąga, co nas jako myślące i czujące istoty zajmuje. Można by więc nazwać to po polsku zajęcie, jak mówimy np. ta sztuka mię bardzo zajmuje. Lecz wyraz ten jest do czego innego użyty i mógłby być dwuznacznym. Przy tym my czynimy różnicę między zajęciem a przejęciem. U nas zajmuje się tylko dusza, a przejmuje się serce, mówimy: zajęło mnie to ciekawe zdarzenie, a przejęło mnie to smutne zdarzenie. Zostańmy więc przy tym obecnym nazwaniu.

Każde dzieło sztuki aby było interesownym, mówić powinno do rozumu, do czucia i do imaginacji naszej. Do dwóch ostatnich przemówić nigdy nie zdoła, jeżeli pierwszego nie znajdzie, a tym bardziej gdy go obrazi, które zaś dzieło wszystkie te trzy władze człowieka zająć potrafi, to najwięcej mieć będzie interesu.

Horacy sprawiedliwie powiedział: „sapere principium est et fons”. Mówić więc naprzód będziemy o tym, co w sztukach nasz rozum zajmuje. Możemy w sztukach, w naturze samej widzieć rzecz bardzo naturalną, rozumowi nie przeciwną, która przecież będzie dla nas zupełnie obojętną, na którą tylko dla zabicia czasu patrzymy. Tak próżnujący, patrzy z ognana ludzi idących ulicą bez zajęcia się tym widokiem, tak czytamy jakie obojętne pismo albo słuchamy prelekcji. Tak wszystko przy czym nasza uwaga biernie jest tylko zajętą interesownym zwać się nie może.

Ale jeśli trafimy na przedmiot, który nam o wszystkim innym zapomnieć każe, jeżeli np. jak na widok tragedii, przewidujemy, domyślamy się, czujemy wnioski, jeżeli się w nas obudzają życzenie, nadzieja albo obawa, jeżeli nam idzie o to, aby czuć ten lub inny obrót, jeżeli myślą działamy z osobami sceny, wtenczas ten przedmiot jest interesujący.

Przez takie zajęcie rozumu, poeta najpewniej podobać się może. Dla tego czytamy na przykład cały tom poezji elegicznych, które do samego czucia mówią, pewno doznamy unudzenia, dla tego największy czciciel poezji Osjana, nie może powiedzieć, aby ciągle dłuższą część dum jego czytał z zajęciem, mimo tylu piękności tego poety. Czemu? Bo najwięcej mówi do samej imaginacji, ciekawość nasza, mało w nim jest zaostrzoną, gdy przeciwnie w Iliadzie, gdzie widzimy plan mądry poematu, jedno źródło i jeden cel, wyraziste i rozmaite charaktery, wszystko imaginacją i nasz rozum zajmuje. Czucie nasze chwilowo trwa tylko, imaginacja prędko się w obłędach swoich nuży, ale rozum badający, ciekawy, jak ogień tym więcej się zajmuje, im lepszym podsycany jest materiałem. Przy dziełach samej imaginacji lub czucia, mamy się

\footnotetext{
${ }^{6}$ Horacy, Sztuka poetycka, wers 309: „Mądrość jest początkiem i źródłem pisania”.
} 
jako istoty podległe, tu zaś gdzie nasz rozum jest czynny, działamy sami jako istoty wolne, $\mathrm{z}$ własnych sił działające, $\mathrm{i}$ to jest największy przymiot naszej natury ${ }^{7}$. Tę to czynność, ten interes uważali niektórzy filozofowie za źródło naszych wszelkich ludzkich działań.

Każdy więc pisarz nie może nam więcej pochlebić i podobać się, jak kiedy przez dzieło interesowne, do czynności nasz umysł pobudza. Każdy to przyzna, że te dnie w jego życiu były najszczęśliwsze, w których dusza jego najwięcej czynną się okazała i można powiedzieć, że czynność stanowi miarę i stopień życia naszego.

Interesowne dzieła ważne są przez to, że czynność człowieka pomnażają. Natura nie chciała nas mieć tylko tkliwymi, melancholicznymi, ale żywymi, do działania ochoczymi ludźmi. Tak dzieła wszystkich narodów energicznych, ciekawych, czynnych, zaostrzają naszą uwagę, są żywiołem rozumu i dążą do praktyki, gdy pisma innych ludów są tylko leniwym naśladowaniem, gdy dzieła gnuśnych mieszkańców wschodu są pełne samej prawie imaginacji.

Ale zobaczmy przymioty i warunki sztuki pod tym względem. Ażeby sztuka rozum nasz zająć mogła, powinna mieć naprzód plan, który podobieństwa do prawdy w niczym nie obraził i ciekawość ciągle zaostrzał.

Kiedy piszemy dla samego tylko rozumu, plan dzieła naszego nie jest tak trudny, jeżeli tylko mamy zdrową logikę i pewny zasób materiałów. Ale plan utworu poetyckiego, mówiąc razem do imaginacji i czucia, jeszcze czegoś więcej wymaga.

Weźmy np. jakowe wydarzenie historyczne w celu opisania go dla samego rozumu, które chcemy użyć do epopei i tragedii. Mając wzgląd na to, w historii jedne rzeczy mniej nas zajmują, niżeli drugie, w poemacie zaś wszystkie części zajmować powinny. Powinny być wielkie, aby zadziwienie lub trwogę wzbudziły, niespodziewane, aby przerażały, powinny być rozmaite, tkliwe, zajmujące przez obrazy natury, charakterów, namiętności itd. Dlatego poeta z historycznego zdarzenia wiele wypuści, a wiele utworzyć musi, aby przez wystawienie jednego zdarzenia, interesownie zająć potrafił.

Jakeśmy widzieli, że artyści nie wszystko do sztuk z natury przenoszą, bo natura w utworach swoich nie tylko piękność, lecz i inne widoki miała na

\footnotetext{
${ }^{7}$ W tym miejscu widać wyraźny wpływ pism Fryderyka Schillera, warto zwłaszcza porównać z esejami: O wzniosłości, [w:] F. Schiller, Listy o estetycznym wychowaniu człowieka i inne rozprawy, tłum. J. Prokopiuk Warszawa 1972 oraz O powodach, dla których tematy tragiczne dostarczaja nam przyjemności, [w:] F. Schiller, Goethe i Schiller o dramacie i teatrze. Wybór pism, tłum. O. Dobijanka, Wrocław 1959.
} 
celu, to samo czynią poeci z wypadkami historycznymi. Jak malarz wybie$\mathrm{ra}^{8} \mathrm{w}$ jednej okolicy, to jest tylko najpiękniejsze, tak i poeta $\mathrm{z}$ historii. Wiele zdarzeń dla tego tylko w historii jest zachowanych, że są prawdziwe, chociaż nawet ich przyczyny są niewiadome a skutki mało znaczące. W poezji przeciwnie, przyczyny muszą być jawne, ażeby rzecz zasługiwała na wiarę, skutki muszą być ważne, ażeby ciekawe oczekiwanie wzbudzały. - Dalej historia może być długą jak się podoba i póki jest prawdziwą i uczącą jest zawsze dobra, poema powinno mieć ciąg ograniczony. Nie może być długie dlatego, że, abyśmy o sztuce poety sądzić mogli, potrzeba mieć wyraźnie w pamięci całą rzecz, co w długim poemacie jest niepodobna, po wtóre powinien poeta mówić najwięcej do naszych uczuć i imaginacji, które trwać nigdy długo nie mogą .

Je d n ość. Rozum nasz za pierwszy kładzie warunek, aby dzieło sztuki miało jeden tylko przedmiot, przy którym wszystkie inne uboczne są niepotrzebne, jeżeli nie są do głównego pomocniczymi ${ }^{10}$. Wszystkie części każdego dzieła powinny być nierozdzielnymi od niego częściami. To jest zasada, na której jedynie każde dzieło klasyczne budować się może. Pismo tej nie mające zasady, uważać można jako stół napełniony różnymi sprzętami, z których każdy do czego innego użyty być może i które bynajmniej nie potrzebują stać razem około siebie. Przeciwnie, pismo mające swoją jedność, jest jak zegarek, którego wszystkie części są potrzebne, od siebie nierozdzielne, i wszystkie dążą do jednego celu, do poruszania wskazówek. W tamtych naczyniach

${ }^{8}$ Przekonanie, że zadaniem artysty jest umiejętność wyboru towarzyszy niemalże całej estetyce XVIII wieku, zwłaszcza zaś obecne jest w koncepcjach naturalistycznych początku oświecenia. Ponownie zatem możemy zobaczyć jak bardzo Brodziński korzysta $\mathrm{z}$ teorii francuskiego klasycyzmu. Warto porównać: N. Poussin, [Uwagi o malarstwie] oraz A. Félibien, Wykłady w Królewskiej Akademii Malarstwa i Rzeźby, 1668, [w:] Teoretycy, historiografowie i artyści o sztuce, red. J. Białostocki, Warszawa 1994, s. 186-187 i 518-519; Ch. Batteux, Zasady literatury oraz J.-B. Dubos, Refleksje krytyczne o poezji i malarstwie, [w:] Europejskie źródła myśli estetyczno-literackiej polskiego Oświecenia, Gdańsk 1997, s. 237-238, 135-137.

${ }^{9}$ Dzieło, głosi Brodziński, całą swą siłę i wartość przejawia w działaniu na emocje i wyobraźnię. Im mocniejszy wywoła oddźwięk w naszej duszy, im będzie on trwalszy, tym lepiej dla dzieła sztuki. Podobne podejście do dzieła jako ekspresji emocji znajdziemy u wielu autorów oświeceniowych. Warto zwłaszcza zajrzeć do: J.-B. Dubos, Refleksje krytyczne o poezji i malarstwie, s. 123-127, J.-J. Rousseau, Szkic o pochodzeniu języków, tłum. Bogdan Banasiak, Kraków 2001, a zwłaszcza F. Schillera, O powodach, dla których tematy tragiczne dostarczają nam przyjemności, s. 248-250.

${ }^{10}$ Także przekonanie o jedności w budowaniu akcji dzieła łączy Brodzińskiego z klasycznymi koncepcjami estetyki oświeceniowej. 
widzimy tylko przypadek, który je obok siebie postawił, tu zaś poznajemy istotę myślącą, która tę całość dla pewnego celu utworzyła. Każde więc dzieło powinno mieć swój cel, i ten cel nie może być, jak tylko jeden.

W sztukach pięknych tym bardziej tak być powinno, bo przeznaczeniem tychże jest przyjemne zatrudnienie naszego umysłu, a umysł nasz tak jest organizowany, że tylko na jeden przedmiot może z łatwością zwrócić uwagę, i wszystko co do objaśnienia tego przedmiotu nie pomaga, musi przeszkadzać.

Tak np. mamy obraz Carracci, w którym Archanioł Michał złe duchy do piekła wtrąca, obok tego jest Św. Jerzy, smoka zabijający ${ }^{11}$. Jedno z drugim nie ma żadnego związku. (Tak mamy mnóstwo tragedii, gdzie dwa przedmioty, dwa cele są razem, przy których zajęcie nasze tak jest podzielone, że nas obydwa przestają obchodzić, albo przykre tylko czynią wrażenia).

Szczegółowe warunki tego przedmiotu sztuki wyłuszczę obszerniej przy dziełach dramatycznych, bo tam jedność najważniejszą jest rzeczą. Tu jeszcze w ogólności nadmienię, że jedność nie tylko w przedmiocie samym, ale i w sposobie jej prowadzenia zachować należy.

W poezji ściślej jedność zachowaną być musi, niżeli w innych pismach, chociaż w żadnym być zaniedbaną nie może. W historii np. już ta jedność jest dostateczną, w której wszystkie wypadki ściągają się do jednej osoby, do jednego kraju albo narodu, ale w poezji na tym nie dość, bo te mogą być bardzo rozmaite i sobie przeciwne. Spokojny tylko rozum, może sobie z nich całość rozwinąć, ale poezja nie może zajmować tak długo czasu, bo jej zamiarem nie jest nauczać, ale tylko jedno uczucie wzbudzić. Musi się ograniczyć na jednym ważnym zdarzeniu; wszystkie inne pomniejsze powinny do tego jednego zmierzać i z głównym celem tak się połączyć, ażeby żadna bez obalenia budowy zmienioną i wyrzuconą być nie mogła.

Nie tylko rzecz powinna być jedna w dziele sztuki ale i jeden cel, dla którego ta rzecz jest utworzoną. $Z$ baczności na cel wyniknie jeden ton uczucia, jeden styl, miara i proporcja i to nada dziełu najpożądańszy przedmiot, to jest łatwość i prostotę. Tu rozum czuje najwyższą rozkosz, dla którego to jedność

\footnotetext{
${ }^{11}$ Niestety w spisie dzieł rodziny Carracci nie udało mi się odnaleźć wzmiankowanego przez Brodzińskiego obrazu. Jedność tematyczna, gdzie podstawowy temat może być tylko uzupełniany przez wątki poboczne jest bardzo charakterystycznym rysem znanym estetyce klasycyzującej końca XVII i początku XVIII wieku. Wynika z Arystotelesowskiej koncepcji jedności czasu, miejsca i akcji. Warto porównać: N. Poussin, [Uwagi o malarstwie], s. 187; C. Le Brun, Szósty wykład wygłoszony w Królewskiej Akademii Malarstwa i Rzeźby w sobotę, dnia 5 listopada 1667, [w:] Teoretycy, historiografowie i artyści o sztuce, s. 533 i nn.
} 
i harmonia jest najpożądańszym żywiołem. Nic tak nie obraża obeznanego z dziełami klasycznymi, jak zdania niedojrzałe teraźniejszych krytyków, że dosyć jest, aby się dzieło zdawało naturalnym, że kiedy co w naturze być mogło, to i w sztuce sprawiedliwie zmieścić się powinno. Stąd to ów nieporządek w dziełach romantycznych, owe nieskończone dygresje, mieszanie komiczności z rzeczami smutnymi, a na koniec płaskość aż nadto wiernie z życia potocznego kopiowana. Już oto i u nas drukowane zdania czytamy, że rozum w poezji jest sędzią zimnym i niepotrzebnym, że nie ma prawa wdawać się w dzieła piękności, w utwory czucia. Bada każdemu pismu, które tego sędziego się lęka! Tacy to krytycy mówią, że dzieła klasyczne nie mają oryginalności i same naśladowanie dziwacznych, ciemnych marzeń za oryginalność podają.

Nie masz żadnej czynności ludzkiej, w której by rozum nie powinien być przewodnikiem, a tym bardziej w sztuce, sztuka nie powtarza natury, ale ją udoskonala, a z zadanego przedmiotu wyrobiona jedność i całość stanowi arcydzieło ${ }^{12}$.

Wynalezie nie. Cycero mówi: „Wynalezienie jest wystawieniem rzeczy prawdziwych, albo prawdopodobnych, a wzbudzających zajęcie. Przez to każde dzieło sztuki staje się tym, czym być powinno, to jest całością, pewny cel mającą. - Jeżeli poeta przez namysł i rozwagę tak swoje dzieło ułożył, że zdolne jest osiągnąć zamierzony skutek, wtedy wynalezienie jest dobre"13.

Mówca wynajduje, jeżeli przez namysł przechodzi do wyobrażeń, które wyjaśnią prawdę tego, co dowodzić zamierzał. Wszędzie gdzie mamy zamiary, potrzeba szukać środków, które by cel najłatwiej dopięły, i to jest wynajdywać. Lecz wynalazek poetyczny różni się od wynalazku mówcy. Mówca ma już pewny cel i szuka tylko środków dopięcia owego; poeta przeciwnie, ma już najczęściej pewną materię, i uważa ją jako środek, przez który możne by swój cel osiągnął.

\footnotetext{
${ }^{12}$ Najlepszym przykładem dla tezy Brodzińskiego jest rozprawka Giovanniego Pietro Belloriego, której sam tytuł mówi już wszystko: G. P. Bellori, Idea malarza, rzeźbiarza i architekta wybrana z piękna natury, [lecz] przewyższająca naturę, [w:] Teoretycy, historiografowie i artyści o sztuce, s. 218 i nn. Stanowisko Belloriego najsilniej ukazuje, jak z obserwacji natury przez uogólnienie rodzi się idea w zamyśle artysty. Taki sposób myślenia o powstaniu idei twórcy wyrasta z koncepcji Arystotelesa (Polityka 1281 b 10, Poetyka 1460 b 8) i towarzyszy estetyce XVIII wieku, przynajmniej aż do estetyki Kanta. Warto też zajrzeć do: Ch. Batteux, Zasady literatury, [w:] Europejskie źródła myśli estetyczno-literackiej polskiego Oświecenia, s. 237-239 (rozdz. Geniusz nie powinien naśladować natury taka, jaka jest) oraz I. Kant, Krytyka władzy sądzenia, tłum. J. Gałecki, Warszawa 2004, s. 109 i nn. (\$17).

${ }^{13}$ Cyceron, O wynalazku retorycznem, tłum. K. Żukowski, Wilno 1840, ks. 1, s. 8.
} 
Tak np. czytając jakieś zdarzenie historyczne, widzę iż może być dobrym materiałem tragedii, i ku temu celowi wszystko z niego urządzam.

Takie wynajdywanie jest zawsze dziełem rozumu, który jedynie potrafi łączyć cele z środkami, ale że dzieła sztuki więcej są dla czucia i imaginacji, zatem prócz rozumu, trzeba żywej fantazji i delikatnego czucia, ażeby wynaleźć rzecz godną nazwiska genialnej. Jeżeli poeta ma już pewny zamiar, to jest wrażenie, jakie jego dzieło ma sprawić, wtedy w wiadomościach, w doświadczeniu i w imaginacji swojej wynajdzie wszelkie środki, żywo je obejmie, i stosowną harmonijną całość z nich utworzy.

Nie należy nigdy przypuszczać tego fałszywego wyobrażenia, że samo natchnienie piórem geniusza kieruje, natchnienia nie będzie tam, gdzie nie było wprzódy doświadczenia i głębokiej rozwagi. Wytrwanie tylko i nieobjęte śledzenie obranego przedmiotu, zręczność korzystania z każdej okoliczności do utworu prowadzi. Widzimy w doświadczeniu, że ludzie jaką bądź namiętnością przejęci, najdowcipniejsi są w wynalazki, którymi ją zaspokoić mogą. Skąpy znajdzie wszędzie sposobność coś zyskać, tam nawet, gdzie by to innemu ani na myśl nie przyszło.

Wyobrażenie bogactwa jako największego dobra, zawsze przed oczyma żywo mu stoi, wszystko co z tym ma związek, ściąga jego uwagę, na wszystko patrzy okiem swojej skłonności, zdarzy mu się coś przypadkiem, na co by nikt inny uwagi nie zwrócił, wnet dostrzega związek tej rzeczy z swym głównym celem, że tu można coś zyskać. Takim właśnie sposobem poeta wynajduje, jeżeli wyobrażenie przedsięwziętego dzieła tkwi mu żywo w pamięci. Takim sposobem malarz Eufranor, jak mówi Platon, utworzył postać Jowisza. Myśl jak wyobrazić potęgę Boga pełnego Majestatu zawsze go zajmowała. Raz przechodził przez rynek, gdzie deklamowano Homera, i gdy usłyszał: „Ojciec bogów piorunnym zaczął huczeć grzmotem” - wnet stanął mu na myśli wyraźny ideał władcy Olimpu.

Tak ciągle przejmowanie się rzeczą, prowadzi do żywych o niej wyobrażeń i tworzy ów entuzjazm, który twórczym zowiemy. Stąd dla poetów i artystów uwaga, że w ten sposób, niech to tylko wynajdują, co do obszernego służy zamiaru, niech odsuwają wszystko uboczne, w tym usposobieniu zbiorą wiele zasobów, i na końcu bez trudności najlepsze znajdą. Idzie tylko o to, aby zawsze mieli pewny, wyraźny cel przedsięwziętego dzieła. Kto nie widzi przed sobą celu, zawsze błąkać się będzie. Pisarz, który zaczynając rzecz, nie wie jeszcze na czym ją skończy, nic porządnego napisać nie zdoła, tak jak mówca nie znajdzie dowodów, jeżeli założenia swego jasno i wyraźnie nie objął. 
Wyko nanie. Ale nie dosyć wynaleźć bogate materiały i obrać cel, do którego są zebrane, trzeba myśleć o wykonaniu, to jest ułożyć plan dzieła. Przez plan rozumiemy ilość, wybór i uporządkowanie materiałów, przez które zamierzony cel osiągnąć chcemy. Gdy np. mówca ma zamiar z mianych dowodów jakową prawdę wyświecać, odrzuca najprzód to, co by ją mogło zawikłać, wybiera dowody najmocniejsze i stara się tak je uporządkować, aby jeden przy drugim więcej nabierał mocy, aby wszystkie po sobie następujące służyły do coraz mocniejszego przeświadczenia. Dostrzega, że dowody dajmy na to $A, B, C$, powinny być najmocniej rozwinięte, że w porządku A, B, C, albo C, B, A, po sobie następować powinny. Co do poezji, dajmy na to, że poeta wynalazł zdarzenie w dziejach, w którym wielkie charaktery, śmiałe przedsięwzięcia i ważne skutki napotyka, z czego tragedię lub epopeję utworzyć można. Tu naprzód zwrócił uwagę na charakter przedmiotu, czy li jest wielki, czy tylko zadziwiający, czy wielkość umysłu ludzkiego, czy też skutki namiętności jakiejś lepiej wyświeca, czy głównie do rozumu, czy też do serca, czy też tylko do imaginacji przemówić może. Ta rozwaga wskaże główny zamiar dzieła, do którego plan jego zmierzać powinien, czy ma być wzniosłe, tkliwe, czy przerażające. Do tego powinien wszelkie wypadki wynajdować i stosować tak, ażeby wszystkie jasno i naturalnie się rozwijało, aby coraz nowszymi i mocniejszymi sytuacjami do ostatecznego wrażenia dążyło. W dziele, gdzie plan porządny panuje, każda czynność ma swoją jasną przyczynę; wszystko powinno wypływać z położenia i charakteru osób, a te charaktery powinny być prawdziwe i na naturze oparte. Nie powinno być żadnej przerwy, która by postęp rzeczy zatamowała; chronić trzeba wszystkiego, z czego nie można zdać przed krytyką najściślejszego rachunku.

Upięknienie. Skoro tak wszystko jest uporządkowane i rozłożone, dopiero można zwrócić uwagę na upiększenie, to jest wewnętrznej doskonałości nadać zewnętrzną.

W dziełach wielkich i ważnych przez swą treść, piękność zewnętrzna mniejszą jest rzeczą, przecież ile możności i tu być zaniedbaną nie może, bo wszystko co jest wielkim, jest w naszym wyobrażeniu i pięknym. Tak każdy kto czyta w dziełach o wielkim, dzielnym i cnotliwym człowieku, wystawia sobie w imaginacji jego postać godną tego charakteru.

Tak Scypiona młodszego każdy sobie wystawia, jako dorodnego młodzieńca; każdy, kogo zajmują cnoty Sokratesa, zapomina o jego postaci.

W ogólności, w ułożeniu dobrego planu, trzy potrzeba względy zachować: 1) aby wszystkie części były ze sobą doskonale połączone; 2) aby miały stosowną rozmaitość; 3) aby tworzyły niejakie zawikłanie, przez co umysł nasz 
w ciekawości, a czucie w obawie i nadziei utrzymywać będą. Według tego potrzeba, aby imaginacja główny przedmiot zawsze miała $\mathrm{w}$ pamięci, ale żeby zarazem rozmaicie zajętą była, ażeby rozwiązanie głównego wypadku poprzednimi wstrzymane, ciekawość zaostrzało, aż się na koniec wszystko w jednym głównym wyobrażeniu połączy.

Przy wzmagającym się smaku, który porządek w utworach sztuk pięknych przez naśladowanie Szekspira i Byrona, za małą rzecz ceni, nie znudzę może tych, których to obchodzi, gdy jeszcze dłużej się nad tym przedmiotem zastanowię. Jest bardzo wiele dzieł, które w szczegółach swoich są piękne, a w całości obrazują rozsądek, który we wszystkim chce zgody, harmonii i wykończenia. Są jednak rzeczy, które przez porządek swój są piękne i nic nie znaczą, gdy z niego wyjdą. Tak mnóstwo rozrzuconych kamieni nie zwróci naszej uwagi, ale nas zachwycą, gdy będą okrzesane i w porządną budowę złożone. Tak tony instrumentu niczym są dla nas pojedynczo, lub bez ładu powtarzane, a czarują, gdy postępują według prawideł harmonii i melodii.

Porządek jedynie wzbudza uwagę na przedmiot, nadaje mu upodobanie, czyni go łatwym do pojęcia i zatrzymania w pamięci. Dzieło zaś nieporządne w imaginacji tylko naszej zostawia ślady, bo nie ma dokładnej formy.

Tak budowa w smaku greckim, przez swój porządek bawi oko i łatwo jej wyobrażenie spamiętamy, choćbyśmy ją raz tylko widzieli, gdy budowa gotycka ${ }^{14}$ przez swą rozmaitość utrudza, i w pamięci widza słabe tylko wyobrażenie zostawia. -

Porządek nie tylko na władze umysłu, ale i na czucie i na imaginację naszą ma wpływ nie mały, tak np. odgłos żałobnego bębna, przez same jednotonne uderzenia, pobudza nas do smutku, tak w poezji rytm i mara powtarzana, tak w muzyce wracanie jednego taktu i pewnych części melodii, uczucie w nas wzbudza. Stosowne następstwo słów poety i tonów kompozytora, doprowadzi nas do łez lub oburzenia.

Całość. Każde dzieło sztuki, mające należyty porządek, powinno tworzyć całość, to jest żeby miało swoje ograniczenie i żeby od niczego nie było zawisłym. Właściwie biorąc, świat jest tylko prawdziwą całością, każdy w nim szczegół nie może sam przez się całości składać. Ale dzieło sztuki może być całością ze względu na stanowisko, z którego jest uważane. Jeżeli w nim nie masz nic co do zamiaru tego stanowiska nie należy, o wszystko do niego tylko

${ }^{14}$ To dość powszechne przekonanie w XVIII wieku. Jako jeden z pierwszych przeciwstawia mu się Goethe. Por. J. W. Goethe, O niemieckiej architekturze, tłum. A. Palińska, [w:] Teoretycy, artyści i krytycy o sztuce 1700-1870, Warszawa 1974, s. 214-221. 
dąży, wtenczas można je jako całość uważać i nazywać prawdziwie zupełnym utworem ${ }^{15}$. Można na jedną część zdarzenia tak uwagę zwrócić, że nikt nie pomyśli o całości, do której należy. Poświęcenie np. Ifigenii, jest częścią wojny Trojańskiej, ta wojna jest częścią historii dawnych Greków i Azyanów itd. Ale poeta, który tę tylko małą cząstkę historii jako osobną całość wystawia, powinien zwrócić uwagę jedynie na ofiarę Ifigenii i wystawić rzecz samą z siebie interesowną. Dlatego nie może zaczynać od wojny Trojańskiej, od jej przyczyn, ale zaraz do głównej rzeczy przystąpić.

Dążenie ku doskonałości. Życie rodu ludzkiego jest ciągłym doskonaleniem się. Tej prawdy dowodzą nam dzieje, o tym mówi wewnętrzne przeświadczenie cnotliwych. Nieprzyjacielem godności i szczęścia ludzi jest, kto takie przeświadczenie chce tłumić. Ono stanowi moc i jedność całej społeczności, ono łączy narody i wieki, czas z wiecznością, ziemię niebem.

Wszyscy może wiemy i czujemy, jak potrzeba działać, a przecież nie jesteśmy w stanie tak czynić, jak nam głos wewnętrzny dyktuje.

Więc mamy ideały doskonałości moralnej w pojęciu i wyobraźni naszej, tak jak każdy czuły młodzieniec tworzy sobie ideał doskonałości w swojej wymarzonej kochance. Mamy ideały doskonałości charakterów z dziejów i znajomości ludzki, do uzacnienia człowieka przez poezję tworzonych. Te charaktery nie mogą być niedostępne i nie mogą być tylko dla osobowości tworzone. Jakąż to byłby istotą człowiek, gdyby był doskonałym twórcą, niżeli stworzeniem, gdyby dzieło rąk swoich ku czci, a siebie na poniżenie wystawił! Któż wielbiąc i przejmując się doskonałością moralną, w człowieku widzianą, lub przez człowieka stworzoną, powie uczuciu swojemu, że to nie dla mnie być takim? Powołaniem naszym jest ciągle się w ideały doskonałości wpatrywać i wyszukiwać je w sobie. Życie nasze i życie całej ludzkości ciągłą jest sztuką. Najcnotliwszy o najrozumniejszy mąż, tak postępuje w działaniu moralnym, jak geniusz w utworach swoich. I w życiu jak w sztuce, potrzeba w działaniu mieć przed oczyma wizerunek doskonałości, wcielić się w niego całą miłością, całym pojęciem. Trzeba zadanie wyrozumieć, okrzesać, wyrobić, aby go oddać utworem takim, jaki w wyobraźni naszej już jest stworzony. Jak człowiek fizyczną naturę z dzikości okrzesał, wedle swych potrzeb użył i ozdobił, tak powołaniem jego jest wyrobić i uzacnić swoją naturę moral-

${ }^{15}$ Aby lepiej zrozumieć koncepcję sztuki jako części złożonych w całość na wzór tworu organicznego (wewnętrznie celowego), jaki dominował w XVIII wieku, warto zajrzeć do: M. H. Abrams, Zwierciadło i lampa, tłum. M. B. Fedewicz, Gdańsk 2003, rozdz. VIII (Psychologia twórczości literackiej: nieświadomy geniusz i rozwój organiczny), s. 203 i nn. 
ną. Poezja jako religii kapłanka, idzie przed nim z wieszczym skinieniem, wskazując mu obraz doskonałości, a razem powiększając zwierciadło słabości jego, aby kiedyś sam zdążał do tego, co w krainie piękności pochwala lub gani, co rozum jego uznaje i wewnętrzny głos czucia pochwala. Geniusz widzi przed sobą w przyszłości udoskonalony ród ludzki; - nie rzeczywistość, ale droga, którą jeszcze do celu przebyć potrzeba, sprawia w nim tęsknotę, a czasem godną wyrozumienia zwątpiałość. Ale pojąć nie można aby Bóg, który najlichszego ździebła bez celu nie stworzył, wlał w człowieka na udręczenie tylko i zawstydzenie, całą twórczą siłę i chęć doskonałości. Wszystko co człowiek wyobraża, wyświeca i wyrabia, czyni w tej świętej wierze, iż to, co jest dotąd próbowaniem, marzeniem, kiedyś istotą się stanie i w rzeczywistości się wcieli. Po wszystkie wieki i dotąd marzyli ludzie o wieku złotym, o ludziach i szczęściu doskonaleni, atoli dążeniem być winno, aby te marzenia od przeszłości do przyszłości odwrócić; aby człowiek przez sztukę życia stał się z czasem tym, czym myśli, że przez samą naturę był kiedyś. Tę drogę, tę pracę, tę nadzieję odzyskania raju, wskazał Bóg całemu potomstwu Adama, po siągnieniu ręki do drzewa wiadomości. Zawsze naprzód i naprzód! upadające pokolenie niech następnemu drogę wskazuje. Godniej do czegoś tęsknić, niżeli żałować; spieszyć do celu, nie dumać nad drogami niepowrotnemi. Tęskność używa naprzód słodyczy, a żal i wspomnienie odżuwają tylko boleść, którą się kiedyś karmiły. Żyj życiem ludzkości, a smutek twój będzie wzniosły i pociechy twoje nie doznają zwątpienia.

Jak widzimy dziecię, które zwolna rozwija swój rozum i moralne przymioty, a które dojść może do geniuszu Newtona i cnót Washingtona, tak zwróciwszy oko nadzieje, widzimy ten sam postęp w narodach i w całej ludzkości, choćbyśmy tylko Amerykę północną za przykład wskazali. Żałować należy tych, co tego nie widzą, tych, którzy cząstki przynajmniej do tej budowy nie zostawią po sobie. Żyj w ludzkości i w Bogu, to jest jedyne powołanie, jedyny sposób, aby prawdziwie żyć umysłowo, bez tego istota nasza jest samą tylko fizyczną, cząstki jej przejdą w inna istoty, ale moralne jej życie nie przejdzie w skład świata moralnego.

Otrzymaliśmy zapasy od natury, ale nam zostawiono rozwijać je i uzupełniać w sobie i takie następcom do dalszego doskonalenia zostawić ${ }^{16}$.

Wszystko czym jest człowiek i co ma, winien jest Twórcy, lecz winien także i ludziom: oni utorowali mu drogę, nim przyszedł na świat, na której rozwinie

${ }^{16}$ Por. F. Schiller, O wzniosłości, tłum. J. Prokopiuk, [w:] tenże, Listy o estetycznym wychowaniu człowieka i inne rozprawy, Warszawa 1972, s. 177. 
swe siły i której dalsze ślady następcom zostawi. Rozum wasz jest wspólnym skarbem społeczeństwa, wszyscyśmy od niego coś otrzymali, i wszyscy go dorobkami naszymi zbogacamy. Jakże dziś mało kosztują nas wiadomości i sposoby, które niegdyś z takimi nabywano trudnościami! Ze społeczności dla społeczności żyjemy. Działaj szczerze i w dobrym duchu dla przyjaciela, dla rodziny, wioski i narodu, albo całej ludzkości, zawsze działasz na ogół. Głównym skarbem ludzkości jest użycie wszelkich możnych sił, wydoskonalenie wszelkich zdolności. Nie tylko ziemi dziedzictwa odbieramy po ojcach, ale dziedzictwo tradycji, dążeń, i nadziei, które utrzymać i szerzyć w bliższym czy dalszym obrębie winniśmy. Zastawszy żniwo, winniśmy obsiać pole dla tych, co po nas przyjdą. Tym uczuciem przejmuje się tylko ten, kto daleki od egoizmu, kto się czuje połączony z ludźmi i światem nadziemskim. Pisarz tym przekonaniem utwierdzony, innym okiem zapatruje się na świat. Nie sam rozum śledzący wszystko, nie sama imaginacja we wszystko się wmarzyć i wszystko ożywić zdolna, ale owa w Bogu pojęta miłość wszystkiego co było, jest i będzie zajęcia godnym, potrafi odgadnąć i wskazać do czego świat dąży. Tym uczuciem tchną prawdziwe geniusze. Co filozof umie odkryć, to geniusz poetycki da pojąć i uczuć, jako rówiennik ludzi i przyjaciel, często nawet jako nieprzyjaciel, złą ich tylko stronę widzący, ale nigdy jako samolub nie chcący mieć spólnictwa w zadaniu, nad którym współbliźni jego pracują.

Piękności miejscowe. Dla lepszego więc zrozumienia interesowności w dziełach pięknych, potrzeba jeszcze zwrócić uwagę na to, co nazywamy pięknością miejscową, jak ją niektórzy zowią, a która to samo znaczy, co smak narodowy.

Jak w tragedii tak w epopei więcej nas zajmują osoby już z dziejów znane, niżeli tylko w imaginacji poety utworzone, tak więcej mają dla nas interesu obyczaje i zwyczaje nasze, albo nam znane, których przypomnienie w dziele widzimy. Prócz tego co narody ogólnie jako ludzi dotyczy, ma każdy naród swoje własne przymioty i dumę narodową i to wszystko w dziełach bliżej go interesuje, stąd wypływa, że każdy naród ze swojego stanu i dziejów utworzył sobie smak odrębny i w dziełach sztuki, i w nich to go zajmuje, co dla obcego jest obojętnym ${ }^{17}$. Smak każdego ludu zawisł od klimatu, religii, rządu itd. w klimacie zimnym będzie miał smak w architekturze i ubiorach, który się nie zgodzi ze smakiem innego klimatu, w sielankach Teokrata i Wirgiliusza

${ }^{17}$ Jedną z pierwszych koncepcji estetycznych (a być może pierwszą) podejmujących zagadnienie związków pomiędzy geniuszem a środowiskiem naturalnym i społecznym są rozważania Jeana-Baptista Dubos. Por. J.-B. Dubos, Refleksje krytyczne o poezji i malarstwie, s. 142-144. 
słyszymy wszędzie mruczące strumyki, wszędzie łagodną, wesołymi istotami zaludnioną naturę, ale Thompson np. śpiewając pod innym niebem, wcale inną maluje naturę ${ }^{18}$. Każdy z nich mówi stosownie do miejscowości swojego kraju. I tej różnicy smaku nie można żadnemu mieć za złe, idzie tylko o to, czy Wirgiliusz, czy Thompson swoje obrazy lepiej malował. W Rzeczachpospolitych więcej kwitnie wymowa, niż poezja, w innych rządach więcej się objawia talent podobania się przez poezję. Tam dzieła noszą piętno większej energii i charakteru, tu więcej delikatnego dowcipu ${ }^{19}$. W narodzie poważnym mają dzieła więcej okazałości i prostoty, w narodzie wesołym więcej rozmaitości i wdzięków, w klimacie zimnym więcej ludzie rozumują, w umiarkowanym mają więcej smaku i dowcipu, w gorącym więcej mają uniesień. Śmieszności jednego ludu nie należą do drugiego, dla tego różne te narody nie mogą mieć jednego rodzaju komedii. Komedia jest rodzajem poezji, poświęconym zupełnie prawie miejscowości, ponieważ ma za cel tylko obyczaje, które wszędzie tak są przemienne i rozmaite. Dlatego komedie tracą zawsze w potomności, albo do innego kraju przeniesione. Już niektóre dzieła Moliera nie mają tego interesu, jaki w swoim czasie mieć mogły. Czytanie komedii Plauta i Terencyusza słabo tylko przypomina nam wrażenie, jakie na Rzymianach czynić musiały. Lecz co do tragedii i epopei powiedzieć można, że jak pisarze komedii są tylko ludźmi swojego kraju i wieku, tak epopeja i tragedia do wszystkich krajów i wieków należy, bo te malują ludzi jako ludzi z ogólnych ideałów, a miejscowość jest dla nich nie rzeczą główną, ale tylko pomocniczą. Wszyscy wielcy poeci, którzy nie wyłącznie z szczególnych towarzystw, ale ogólnie z natury czerpali, tak są trwałym jak ona ${ }^{20}$. Dla tego Homer, Wirgiliusz, Fénelon i La Fontaine, mają piękności, nie zawierając nic miejscowego, a które przecież należą do potomności i całego rodu ludzkiego.

$\mathrm{W}$ ogólności jest $\mathrm{w}$ tym względzie szczęśliwa równowaga między poetą komicznym a tragicznym lub bohaterskim, którego poznanie, może dla oby-

\footnotetext{
${ }^{18}$ Warto porównać koncepcję estetyczną ojca André, który wprowadza pojęcie piękna naturalnego. Zob. Y. M. André, Essai sur le beau, Paris 1810, s. 19.

${ }^{19}$ Najpewniej są to dalekie echa studiów, jakie Brodziński przeprowadził nad wczesnymi rozważaniami Kanta dotyczącymi piękna i wzniosłości. Por. I. Kant, Rozważania o uczuciu piękna i wzniosłości, [w:] I. Kant, Dzieła zebrane, t. 1, Toruń 2010, s. 661-663.

${ }^{20}$ Warto porównać Bellorie’go i Batteux krytykę twórców nowożytnych za odchodzenie od natury jako źródła inspiracji dla sztuki. Zob. G. P. Bellori, Idea malarza, rzeźbiarza i architekta wybrana z piękna natury, [lecz] przewyższająca naturę, [w:] Teoretycy, historiografowie i artyści o sztuce, s. 225-226 oraz Ch. Batteux, Zasady literatury, [w:] Europejskie źródła myśli estetyczno-literackiej polskiego Oświecenia, s. 236.
} 
dwu korzystne wydać przepisy. Jak poeta komiczny dla udoskonalenia swych dzieł powinien charaktery idealizować, mając miejscowość głównie na celu, tak poeta tragiczny zajmując się głównie idealnymi charakterami, powinien się starać, aby je przez miejscowość interesownymi uczynić. Potrzeba ideał, któryby mógł ten charakter reprezentować, urzeczywistnić.

Dla tego sztuką poety jest, ażeby w rozważaniu charakterów szczególnych, przyszedł do wystawiania ogólnych. Kunszt zaś zawisł tu na tym, aby ten ogólny charakter nosił najwyraźniejszą cechę miejscowości. Krótki przykład niech to objaśni. Plaut i Molier dali nam obraz Skąpca, każdy w swoim rodzaju. Schlegel porównując obydwu, mówi, że Euclion Plauta ma więcej prostoty, że zdarzenie skarbu ukrytego, jedynego źródła niespokojności Eucliona, w całej sztuce panuje, gdy tymczasem Molier użył więcej ubocznych zdarzeń, i cała rzecz więcej ma w Plaucie jedności. Pod tym względem każdy zapewne zgodzi się ze zdaniem Schlegla. Sam tytuł Plauta Sk a r b dowodzi, że poeta nie miał zamiaru wystawić ideału skąpca, ale tylko obok zdarzonego wypadku portret onego.

Molier inny miał pomysł. Zamierzył on wystawić w jednej osobie ideał skąpstwa i poddać Harpagona pod wszystkie próby, użył wszelkich obrazów miejscowości, które tę namiętność najkorzystniej wystawić mogą. Molier zatem przewyższył Plauta w swoim utworze. Dla tego tłumacze lub naśladowcy komedii obcych, słusznie u nas czynią, gdy niewiernie tłumaczą, ale gdy charakter i zdarzenie obcej komedii, mogące ogólnie interesować, do miejscowości stosują. Chybiają tylko wtenczas, kiedy wady i obyczaje, jakie narodowi naszemu są obce, chcą nam niejako przyswoić. Odmiennie lubo na tychże zasadach postępuje tragedia i epopeja. W tych miejscowość nie tak ważną jest rzeczą, jak ideał charakterów i obyczajów. Miejscowość jest tu już tylko rzeczą poboczną, środkiem do uzmysłowienia ideału, który tu głównym jest celem. W tragediach nie potrzeba już miejscowości w szczegółach wystawiać, ale cały naród i wiek, w którym rzecz się dzieje idealizować.

W tragediach potrzeba nie tylko szczególne zdarzenie uzupełnić, nie tylko dać ideał szczególnego charakteru i namiętności, ale ideał narodu i wieku w jednej osobie i w jednym zdarzeniu zebrany i uzupełniony. Jeżeli więc dobrze czynimy, przepolszcząjąc obce komedie, tak słuszny prostych naśladowców znosimy wyrzut, gdy w tragediach polskich kopiujemy bohaterów z tragedii francuskich. Dlatego to mimo patriotyzmu żądzy o sławę narodową, sztuki te nie pozostają w sercu naszym. Chwalimy je, łudząc się jak mogąc narodowością. 
Ale gdyby poeta przejąwszy się dziejami, obyczajami narodu np. wieków Zygmuntowskich, chciał nam skupić ich obraz w jednym zdarzeniu, w jednej osobie, jakże byśmy inne o poezji narodowej powzięli wyobrażenie. Gdyby nam np. w sporze Zamojskiego ze Zborowskim, Jana Kazimierza z Lubomirskim itp. wystawiono ideał obywatelstwa i charakteru Polaków, wyczerpany nie tylko $\mathrm{z}$ ich szczególnych przymiotów, ale z przymiotów całego w owym wieku narodu.

Takich nam tragedii życzyć należy, aby pisarze nie tylko Racina i Corneilla czytali, z których reminiscencje przestaną przecież być dla nas nowymi, ale żeby zechcieli badać jak Szekspir i Schiller umieją dać barwę miejscowości rzeczom, które malują, a najwięcej, aby dzieje polskie w szczegółach czytali i rozbierali, bez czego nie podobna być dobrym dramatycznym poetą. Racine znał na pamięć nie tylko Eurypidesa jako wzór, ale dzieje starożytne jako źródło, za pomocą którego mógł mu wyrównać.

Jak sam Eurypides nie nauczał Racina, tak i nas sam Racine nie nauczy pisać tragedii. Racine zawiera równie rzeczy do miejscowości Francji i wieku jego należące, których z niego naśladować jest dla nas nie stosownie.

Lecz dodać na koniec potrzeba, że w malowaniu miejscowości poeta szczególniej chronić się powinien, aby nie pochlebiał przesądom, słabościom i fałszywej dumie narodowej (że już nie mówię złym obyczajom). Owszem niech wybiera tylko, co według jego ideałów widzi w skłonnościach narodu najpiękniejszym, co stanowi i potrzebom jego najwięcej odpowiada, zgoła powinien się zniżać do powszechności tak tylko, aby ją, wywyższać ku sobie. Czasem przez jeden geniusz może być naród naprowadzony na drogę prawdziwego smaku i oświecenia, jak przeciwnie płochy talent może ją, zrobić lekką, i rozwiązłą. Są ludzie tak tępych zmysłów, których w utworach sztuki nic nie interesuje, więcej takich, którzy cząstkowo tylko piękności sztuki pojąć są w stanie. Umysł zimny ${ }^{21}$ i rachujący będzie szukał tylko związku pomysłów. Surowy gramatyk tylko własności wyrażeń. Ten z imaginacją będzie chwytał same błyskotki. Inny nie sądzi o dziele, tylko ze stosunków przypadkowych, jakie z jego stanem mieć może. Na koniec są piękności, które jednego zachwycą, a drugiego nawet uwagi nie zwrócą. Jednakowoż ogólnie biorąc sąd publiczności miejscowej zawsze jest słusznym, przeto samo że każdy uważa

\footnotetext{
${ }^{21}$ Jak pisał Wolter w Encyklopedii pod hasłem smak: „Są dusze zimne, fałszywe, które się nie rozgrzeją, nie naprostują. To są ci, z którymi nie należy dyskutować o smaku, ponieważ żadnego nie mają". Por. Encyclopédie, ou Dictionnaire raisonné des sciences, des arts et des métiers, Stuttgart, Bad Cannstatt 1995, Vol. 7, s. 761. (cytat za: M. Żelazny, Estetyka filozoficzna, Toruń 2010, s. 50).
} 
rzecz z innego stanowiska, i że pisarz każdemu zadość uczynić powinien, wyjąwszy wtenczas, gdy publiczność sama fałszywym smakiem jest uwiedzioną. Wielu może dobrze sądzić o szczegółach, lecz mało kto o całości. Dla tego autor mieć zawsze na myśli powinien nie wielką liczbę reprezentantów publiczności, i tym jedynie starać się zadość uczynić.

Opracowała Kinga Kaśkiewicz 